Article

\title{
Long-Term Irrigation with Treated Municipal Wastewater from the Wadi-Musa Region: Soil Heavy Metal Accumulation, Uptake and Partitioning in Olive Trees
}

\author{
Khaled A. Al-Habahbeh ${ }^{1}$, Mohamed B. Al-Nawaiseh ${ }^{1}$, Rabea S. Al-Sayaydeh ${ }^{1}$, Jehad S. Al-Hawadi ${ }^{1}$, \\ Randa N. Albdaiwi ${ }^{2}$, Hmoud S. Al-Debei ${ }^{3}$ and Jamal Y. Ayad ${ }^{3, *(D)}$ \\ 1 Department of Agriculture Sciences, Faculty of Shoubak College, Al-Balqa Applied University, \\ Al-Salt 19117, Jordan; habahbeh@bau.edu.jo (K.A.A.-H.); dr.mnawaiseh@bau.edu.jo (M.B.A.-N.); \\ rabea.sayaydeh@bau.edu.jo (R.S.A.-S.); jehad_77@bau.edu.jo (J.S.A.-H.) \\ 2 Department of Land, Water and Environment, School of Agriculture, The University of Jordan, \\ Amman 11942, Jordan; randa.rahahla@ju.edu.jo \\ 3 Department of Horticulture and Crop Science, School of Agriculture, The University of Jordan, \\ Amman 11942, Jordan; debeih@ju.edu.jo \\ * Correspondence: ayadj@ju.edu.jo; Tel.: +00-962-797232229
}

check for updates

Citation: Al-Habahbeh, K.A.; Al-Nawaiseh, M.B.; Al-Sayaydeh, R.S.; Al-Hawadi, J.S.; Albdaiwi, R.N.; Al-Debei, H.S.; Ayad, J.Y. Long-Term Irrigation with Treated Municipal Wastewater from the Wadi-Musa Region: Soil Heavy Metal Accumulation, Uptake and Partitioning in Olive Trees. Horticulturae 2021, 7, 152. https:// doi.org/10.3390/horticulturae7060152

Academic Editor:

Alessandra Francini

Received: 30 May 2021

Accepted: 11 June 2021

Published: 13 June 2021

Publisher's Note: MDPI stays neutral with regard to jurisdictional claims in published maps and institutional affiliations.

Copyright: (c) 2021 by the authors. Licensee MDPI, Basel, Switzerland. This article is an open access article distributed under the terms and conditions of the Creative Commons Attribution (CC BY) license (https:// creativecommons.org/licenses/by/ $4.0 /)$.

\begin{abstract}
Utilization of treated wastewater (TWW) for agricultural purposes has grown over the past few years because of limited available water resources. This study was performed to assess the long-term irrigation of treated wastewater from the Wadi-Musa region on the accumulation of heavy metals in soil and their uptake and translocation to various parts of olive trees. Fifteen year old trees that had been grown and irrigated with treated wastewater resources since their establishment were used in this study. Irrigation water, soil, and plant samples (root, stem bark, leaves, fruits) were collected and chemically analyzed for their heavy metal content. Accumulation of heavy metals in irrigation water and soil were found to be within the acceptable range for the safe use of treated wastewater according to the standards of the WHO. However, long-term and continuous irrigation with TWW resulted in significant accumulation of heavy metals in plant parts when compared to their levels in irrigation water and soil. Uptake of metals was consistent among plant parts with the highest concentrations for $\mathrm{Fe}, \mathrm{Mn}, \mathrm{Pb}$ and $\mathrm{Zn}$, and the lowest concentrations for $\mathrm{Ni}, \mathrm{Cr}$ and $\mathrm{Cd}$. Assessment of the bioaccumulation factor (BFC) and translocation factors (TF) of heavy metals into different plant parts indicated selective absorption and partitioning of these heavy metals into different plant parts. High BCF values were observed for $\mathrm{Fe}, \mathrm{Cu}$ and $\mathrm{Ni}$ in roots and fruits, and $\mathrm{Fe}$, $\mathrm{Mn}, \mathrm{Cd}$ and $\mathrm{Pb}$ in leaves. Translocation factors of metal ions were variable among plant parts. Fruits had the highest TF for $\mathrm{Cu}, \mathrm{Cd}$ and $\mathrm{Zn}$ metals, and the lowest for Mn and Fe, while leaves have the highest TF for $\mathrm{Fe}, \mathrm{Zn}$ and $\mathrm{Mn}$ and the lowest for $\mathrm{Cd}$ and $\mathrm{Pb}$. The results of this study indicate that olive trees are heavy metal accumulators, caution should be considered in long-term use of TWW and periodic assessment of possible hazards, especially on fruits and oil quality is required.
\end{abstract}

Keywords: bioconcentration factor; heavy metals; irrigation; Olea europaea L.; translocation factor; treated wastewater

\section{Introduction}

Jordan is considered one of the countries most affected by climate change, with a marked decrease in precipitation over the past few decades [1]. This has increased the negative impact of drought and water shortage on crop growth and productivity of major agronomic crops $[2,3]$. Jordan is considered the fourth poorest country in the world in terms of water resources [4]. Overuse of water resources due to increased population growth and the influx of refugees has resulted in a large depletion over the last few decades. The water deficit is estimated to increase from about 160 million $\mathrm{m}^{3}$ in the year 2015 to 490 million $\mathrm{m}^{3}$ 
by the year 2025 [5]. Climate change and changing precipitation patterns will aggravate the problem.

Sustainable utilization of water resources necessitates the utilization of alternative water resources such as treated wastewater, especially for irrigation purposes to minimize the damage of depleting freshwater resources [6]. Supplementary irrigation has been considered a major factor for increasing crop productivity in arid and semiarid environments [7]. Farmers have developed techniques for the use of marginal water, such as treated wastewater (TWW), as a supplementary source of irrigation water. Department of statistics records indicate that about 160 million $\mathrm{m}^{3}$ of TWW was used in 2018, mainly for irrigation purposes, which represents about $14 \%$ of total water consumption [8]. Whereas TWW can be used at reasonable rates to improve plant growth and production under drought conditions [9], the main challenge of using TWW is the high risk of soil pollution and phytotoxicity due to the hazardous accumulation of salts and heavy metals [10]. Heavy metal contamination has been reported in soils irrigated with TWW effluents in different regions across Jordan regardless of the low heavy metal content present in the effluents [11,12]. Contradicting results have been reported about increased levels of soil $\mathrm{Pb}$, $\mathrm{Cd}, \mathrm{Mn}$ and $\mathrm{Cu}$ [13], and low levels to moderate levels of $\mathrm{Pb}, \mathrm{Cu}, \mathrm{Zn}$ and $\mathrm{Cr}$ [14] along the Zarqa river basin in response to irrigation with TWW effluents.

There is a growing interest in the control of heavy metal accumulation in TWW and in the soil to prevent their uptake by plants and, therefore, prevent their transfer into the food chain and humans [15]. Heavy metals are highly toxic, and their presence in the atmosphere, soil and water, and their accumulation in the food chain, is considered dangerous to human health [16-18]. The olive tree (Olea europaea L.) is the most cultivated fruit tree in the Mediterranean basin. Jordan is among the top ten countries producing olives in the Mediterranean region, where 220 thousand tons of olive yield are harvested from 15 million trees in Jordan annually $[19,20]$. In Jordan, olives are primarily grown under rainfed conditions without supplemental irrigation; however, due to the increased impact of climate change through the increased incidence of drought episodes and increased temperatures, there is a growing need for the use of supplemental irrigation for maintaining crop productivity [21]. Olive trees are considered tolerant to adverse climatic conditions, characterized by their ability to withstand drought [22]. However, an increase in yield is usually obtained when supplementary irrigation is used [23]. Due to the limited freshwater resources in Jordan, olive farmers have been looking for alternative water resources that sustain crop requirements and yet have no negative impact on the environment [24]. Utilization of treated wastewater resources on various crop species, including olive trees, has been evaluated worldwide [25-29]. Plants differ in their absorption, translocation and accumulation of heavy metals in their tissues and organs. Accumulation of trace elements in various organs at concentrations higher than those present in the soil might indicate biohazardous accumulation of these metals, especially in edible parts [30-32]. Environmental pollution with heavy metals is a serious global concern. Uptake of heavy metals by plants from polluted water or soil might contaminate the food chain for both humans and animals. Heavy metals such as $\mathrm{Cu}, \mathrm{Cd}, \mathrm{Cr}, \mathrm{As}, \mathrm{Pb}$ and $\mathrm{Ni}$ were reported in olive oil in Cyprus at concentrations that can cause significant health hazards [33]. Furthermore, Spanish table olives were reported to contain significant levels of $\mathrm{Cd}, \mathrm{Co}$, $\mathrm{Cr}, \mathrm{Li}, \mathrm{Ni}, \mathrm{Pb}$ and $\mathrm{Sr}$ [34]. In this perspective, olive trees are considered important heavy metal bioaccumulators in different plant parts for $\mathrm{Cu}, \mathrm{Pb}$ and $\mathrm{Zn}$ [31]. These high levels of heavy metals such as $\mathrm{Cd}, \mathrm{Pb}, \mathrm{Cr}, \mathrm{Hg}$, and As were reported to have adverse effects on increased oxidative stress and cellular damage to both plants and animals [35]. Further negative effects on human health, such as kidney failure, diabetes, cardiovascular disease, neurotoxic effects, cancers and many other developmental disorders, were reported [36].

Heavy metal content in soils irrigated with TWW has been studied in several locations across Jordan [21,32]. However, less information is available about the irrigation of plants in the Wadi- Musa region. Furthermore, the fate of heavy metals in soils, and their absorption and bioaccumulation in olive plants in response to long-term irrigation with TWW effluents, 
has not been studied before in this region. Therefore, the present study aimed to explore the effects of long-term irrigation with TWW on the accumulation of heavy metals in soils, and of uptake and partitioning of selected heavy metals in olive trees.

\section{Materials and Methods}

\subsection{Study Area, Soil, and Water Characteristics}

This study was carried out at the Wadi-Musa Wastewater Treatment Plant (WMTP), $31 \mathrm{~km}$ to the north of the city of Maan (latitude $30^{\circ} 10^{\prime} \mathrm{N}$ and longitude $35^{\circ} 47^{\prime} \mathrm{E}$ with an elevation of $1069 \mathrm{~m}$ ) near the ancient city of Petra. The Wadi Musa treatment plant handles all wastewater flows from four communities adjacent to the Petra Archaeological Park, with four pump stations located, respectively, in the communities of Wadi-Musa, Tayyibeh, Beidha and Umm Sayhoun [37].

The demonstration farm was established near the WMTP on an area of seven hectares, and an area of $\sim 100$ hectares is used for farming by local tribal communities. The demonstration area is cropped with fodder crops and fruit trees (almond, apricot, lemon, olives, pistachios, and date palm). The location is characterized by a typical eastern Mediterranean climate with low precipitation (annual rainfall average: $170 \mathrm{~mm}$ ) and a hot dry summer with an average maximum temperature that exceeds $30^{\circ} \mathrm{C}$ from June to September (Figure 1). The soil of the experimental site was classified as a typical sandy loam with $\mathrm{pH}$ and EC values of 7.5 and $1.75 \mathrm{dS} \mathrm{m}^{-1}$, respectively, and $13.5 \mathrm{~g} \mathrm{~kg}^{-1}$ organic matter (OM) and $15 \mathrm{~g} \mathrm{~kg}^{-1} \mathrm{CaCO}_{3}$ (Table 1).

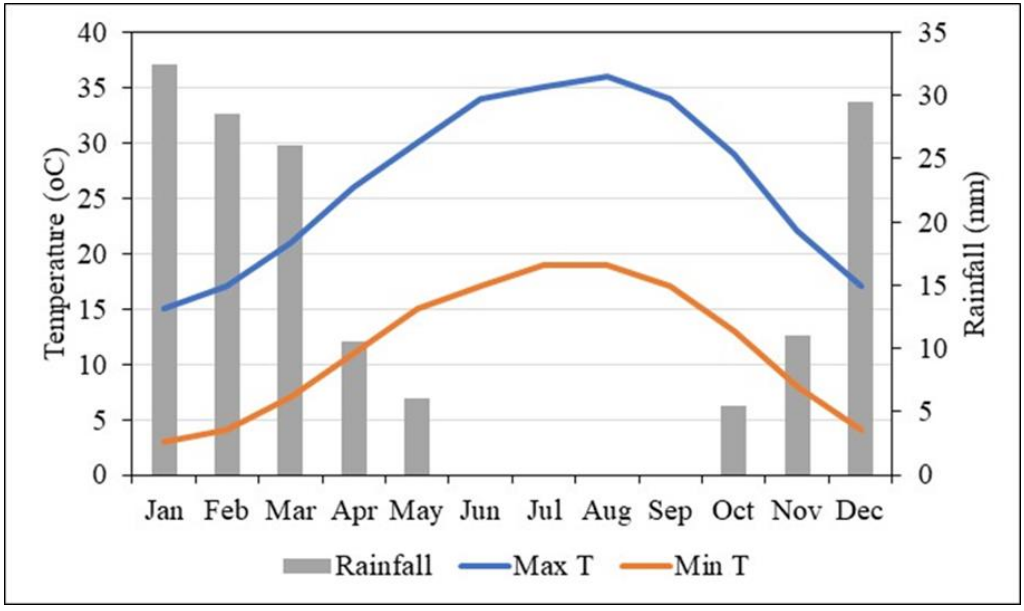

Figure 1. Long-term average monthly minimum and maximum temperatures and average monthly rainfall at the Wadi-Musa Wastewater Treatment Plant experimental site.

Table 1. Main physical and chemical properties of soil at the Wadi-Musa Wastewater Treatment Plant experimental site. The data are averages $\pm \operatorname{SD}(n=3)$.

\begin{tabular}{ccc}
\hline Soil Analysis & Unit & Measurement \\
\hline Sand & $20-200 \mu \mathrm{m}$ & $78.4 \pm 6.1$ \\
Silt & $2-20 \mu \mathrm{m}$ & $12.7 \pm 0.90$ \\
Clay & $<2 \mu \mathrm{m}$ & $8.9 \pm 0.71$ \\
\hline Texture & & Loamy-sand \\
\hline EC & $\left(\mathrm{dS} \mathrm{m}^{-1}\right)$ & \\
pH & & $8.2 \pm 0.52$ \\
$\mathrm{OM}$ & $\left(\mathrm{g} \mathrm{kg}^{-1}\right)$ & $13.5 \pm 0.97$ \\
$\mathrm{CaCO}_{3}$ & $\left(\mathrm{~g} \mathrm{~kg}^{-1}\right)$ & $15.0 \pm 1.04$ \\
\hline
\end{tabular}

The study was conducted on 15-year-old olive trees (O. europaea L. cv. 'Nabali Baladi') cultivated with a density of 420 trees/ha. Trees were irrigated continuously over the 
past 15 years with treated wastewater effluents from the treatment plant. The trees are irrigated twice a week using a drip irrigation system with an average total water supply of $1300 \mathrm{~m}^{3} \mathrm{ha}^{-1}$ year $^{-1}$. Samples of treated wastewater effluents used for irrigating olive trees during 2020 growing season were collected and their average physiochemical analysis is shown in Table 2. Analysis of effluents indicated that irrigation water $\mathrm{pH}, \mathrm{EC}$ and biological oxygen demand (BOD), chemical oxygen demand (COD), total dissolved solids (TDS), sodium adsorption ratio (SAR) and total coliforms count (MPN/100 mL) lie within the standards of Jordan Standards and Metrology Organization [38], and the safe use of treated wastewater for irrigation by the World Health Organization [39]. Bacterial load in treated wastewater was below the levels that restrict their use for irrigation purposes [38,39].

Table 2. Physiochemical analysis of treated municipal wastewater effluents at the Wadi-Musa Wastewater Treatment Plant during the growing season of 2020.

\begin{tabular}{cccc}
\hline Parameter & TWW & JISM $^{\mathbf{1}}$ & WHO $^{\mathbf{2}}$ \\
\hline $\mathrm{pH}$ & 7.78 & $6.0-9.0$ & $6.5-8.0$ \\
$\mathrm{EC}\left(\mathrm{dS} \mathrm{m}^{-1}\right)$ & 1.81 & $1.0-3.0$ & $0.7-3.0$ \\
$\mathrm{BOD}^{\left(\mathrm{mg} \mathrm{L}^{-1}\right)}$ & 10 & 60 & 300 \\
${\mathrm{COD}\left(\mathrm{mg} \mathrm{L}^{-1}\right)}^{\mathrm{TDS}\left(\mathrm{mg} \mathrm{L}^{-1}\right)}$ & 28.3 & 120 & 500 \\
SAR $(\mathrm{ratio})$ & 826.3 & $<2000$ & $450-2000$ \\
Total Coliforms & 8.3 & 9 & $<13$ \\
(MPN/100 $\mathrm{mL})$ & $<1.8$ & $<10$ & $<9$
\end{tabular}

${ }^{1}$ JISM, Jordan Institution for Standard and Metrology; ${ }^{2}$ WHO, World Health Organization. MPN, most probable number.

\subsection{Sampling and Analysis}

Random samples of the olive plant, soil and irrigation water were collected and prepared as described below for the analysis of the heavy metals iron, manganese, copper, zinc, cadmium, lead, chromium, and nickel.

\subsubsection{Plant Sampling}

Olive trees were sampled for their roots, stem bark, leaves and fruits in November 2020. The roots of each olive tree were sampled using a soil corer (five $\mathrm{cm}$ in diameter). The samples were taken $50-75 \mathrm{~cm}$ from the stems to a depth of about $0-50 \mathrm{~cm}$. Roots around two $2 \mathrm{~mm}$ in diameter were washed under running tap water and dried at $60{ }^{\circ} \mathrm{C}$ for $48 \mathrm{~h}$. Stem bark samples were also collected from the outer $3 \mathrm{~mm}$ of the olive tree trunk at $1.5 \mathrm{~m}$ above the ground level using a sharp knife. Collected stem bark materials were dried at $60{ }^{\circ} \mathrm{C}$ for $48 \mathrm{~h}$. Fully mature leaf samples were collected from the upper $5 \mathrm{~cm}$ of one-year old twigs selected from different locations in the canopy. Collected leaf samples were dried at $60^{\circ} \mathrm{C}$ for $48 \mathrm{~h}$. Samples of dried roots, stem bark and leaves were ground using LFJ-20B Hammer grinder (Guangzhou Duoshun Machinery Co., Ltd., Guangzhou, China). The samples were sieved to a $2 \mathrm{~mm}$ mesh size and stored for chemical analysis. Fully ripened fruit samples were collected at maturity harvest time (green to purple stage). Fruits were dried at $75{ }^{\circ} \mathrm{C}$ to a fixed weight and crushed with an Abencor (MC2, Ingenieria Y Systems, Seville, Spain) hummer crusher. Prepared root, stem bark, leaves, and fruit samples were used for the analysis of $\mathrm{Fe}, \mathrm{Mn}, \mathrm{Cu}, \mathrm{Zn}, \mathrm{Cd}, \mathrm{Pb}, \mathrm{Cr}$ and $\mathrm{Ni}$.

\subsubsection{Irrigation Water and Soil Sampling}

Irrigation water was sampled three times from June to November 2020 during the growing season. Irrigation water samples were collected from the drip irrigation lines nearest to the tree. Collected samples were filtrated before adding a few drops of concentrated $\mathrm{HNO}_{3}$ and stored at $4{ }^{\circ} \mathrm{C}$ for chemical analysis. Random soil sampling was also collected at the experimental site at the same time as sampling plant parts. Samples were collected from the upper $0-30 \mathrm{~cm}$ using a soil corer $(5 \mathrm{~cm}$ in diameter). The samples were taken 
50-100 $\mathrm{cm}$ away from the main trunk. Soils were sieved through a $2 \mathrm{~mm}$ sieve and dried at $75^{\circ} \mathrm{C}$ for $48 \mathrm{~h}$ before analyses of heavy metals according to [40].

\subsubsection{Heavy Metals Analysis of Plant, Soil and Water}

Soil, root, bark, and leaf samples were analyzed for $\mathrm{Fe}, \mathrm{Mn}, \mathrm{Cu}, \mathrm{Zn}, \mathrm{Cd}, \mathrm{Pb}, \mathrm{Cr}$ and $\mathrm{Ni}$ using the procedure of Estefan et al. [41]. Samples ( $0.5 \mathrm{~g}$ each of soil, bark, leaves and fruits) were digested in a mixture of four $\mathrm{ml}$ of $\mathrm{HNO}_{3}(70 \%)$ and one $\mathrm{ml}$ of $\mathrm{HClO}_{4}(62 \%)$ using a Microwave Labstation System model ETHOS 9000 equipped with a control unit terminal 240 [41]. Then, the digested samples were filtered through a $45-\mu \mathrm{m}$ filter, and the final solutions were filled to $25 \mathrm{~mL}$ in volumetric flasks with $1 \%$ (v/v) $\mathrm{HNO}_{3}$ solution. Subsequent, analysis of heavy metals was performed with an atomic absorption spectrophotometer (Analyst 200, PerkinElmer, Waltham, MA, USA). Wastewater samples were filtered through a $0.45 \mu \mathrm{m}$ filter and acidified with $\mathrm{HNO}_{3}(70 \%)$ and analyzed according to the methods of the soil, plant and water analysis manual by Estefan et al. [41].

\subsubsection{Bioconcentration and Translocation Factors}

The bioconcentration factor (BCF) and the translocation factor (TF) were used to determine uptake and translocation of various heavy metals into various olive tree organs as described by Mellem [42]:

$$
\begin{gathered}
\mathrm{BCF}=\frac{\text { concentration in organ }}{\text { concentration in soil }} \\
\mathrm{TF}=\frac{\text { BCF of bark or leaf or fruit }}{\text { BCF of root }}
\end{gathered}
$$

\subsection{Statistical Analysis}

A completely randomized design with three replicates for each collected sample was used. A composite sample was prepared from four collected subsamples of plant, soil and water. The uptake and accumulation of various heavy metals in different parts of olive trees in response to long-term irrigation with treated wastewater were subjected to analysis of variance (type I ANOVA) using the Statistical Analysis System (SAS; Version 9.3 for Windows; SAS Institute, Cary, NC, USA), and standard deviations were used for means separation.

\section{Results and Discussion}

\subsection{Chemical Analysis of Irrigation Water and Soil}

The composition of heavy metals in irrigation water and soil samples are shown in Tables 3 and 4, respectively. No significant amounts of copper and manganese were detected in the TWW used for irrigation (Table 3). On the other hand, relatively high amounts of iron, lead and zinc were detected compared to cadmium, chromium and nickel. Based on JISM [38] and WHO [39] standards, the concentration of various ions in the irrigation water was within the acceptable range for the safe use of TWW. Results of the chemical analysis of TWW match those of other studied sites in Jordan, especially that in which municipal water is used and where no industrial effluents are being disposed [25,32,43].

The chemical analysis of soil samples showed that the contents of N, P, K, Na and $\mathrm{Cl}$ were considerably high suggesting some fertilizing effects in response to irrigation with TWW (Table 4). Such increase in ions content could be attributed to increased solubility and organic matter adsorption resulting from TWW irrigation [44-46]. For instance, the availability of $\mathrm{P}$ and $\mathrm{K}$ was correlated with higher organic matter content in TWW [45]. Such increases in nutrient availability in the soil is beneficial for crop growth and productivity [21,25], which might reduce the need for the application of commercial fertilizers. However, a noticeable accumulation of both $\mathrm{Na}$ and $\mathrm{Cl}$ in the TWW-irrigated soil was observed in this study (Table 4). Concentrations reached 345 and $749 \mathrm{mg} \cdot \mathrm{kg}^{-1}$ for both $\mathrm{Na}$ and $\mathrm{Cl}$, respectively. The high $\mathrm{Na}$ and $\mathrm{Cl}$ concentrations in the soil solution could be attributed to the high 
content of these ions in the TWW, and the antagonistic activity of other ions such as K that limit $\mathrm{Na}$ adsorption to the soil particles [44,47]. On the other hand, comparatively low soil heavy metals levels might suggest the possibility of higher plant uptake of these elements to the extent that their levels in soils may have been significantly lowered [48]. On the contrary, the higher levels of $\mathrm{Fe}, \mathrm{Mn}$, and $\mathrm{Pb}$ in the soil might suggest that crop uptake of these elements is not as high as others, or that TWW causes a buildup of soil heavy metal in cultivated soils [48].

Table 3. Chemical analysis of various nutrient and metal ions in TWW used to irrigate olive trees at the Wadi-Musa Wastewater Treatment Plant compared with allowable Jordanian (JISM) and WHO standard limits for irrigation water. The data are averages $\pm \operatorname{SD}(n=3)$.

\begin{tabular}{cccc}
\hline Element & TWW & JISM $^{\mathbf{1}}$ & WHO $^{\mathbf{2}}$ \\
\hline $\mathrm{N}\left(\mathrm{mg} \mathrm{L}^{-1}\right)$ & $11.9 \pm 1.49$ & 50 & $5-50$ \\
$\mathrm{PO}_{4}\left(\mathrm{mg} \mathrm{L}^{-1}\right)$ & $15.2 \pm 1.21$ & 30 & 30 \\
$\mathrm{NO}_{3}\left(\mathrm{mg} \mathrm{L}^{-1}\right)$ & $38.9 \pm 3.74$ & 45 & 50 \\
$\mathrm{Ca}\left(\mathrm{mg} \mathrm{L}^{-1}\right)$ & $81.2 \pm 4.44$ & 400 & 230 \\
$\mathrm{Mg}\left(\mathrm{mg} \mathrm{L}^{-1}\right)$ & $14.6 \pm 1.32$ & 60 & 60 \\
$\mathrm{~K}\left(\mathrm{mg} \mathrm{L}^{-1}\right)$ & $34.2 \pm 3.29$ & 80 & 80 \\
$\mathrm{Na}\left(\mathrm{mg} \mathrm{L}^{-1}\right)$ & $94.2 \pm 5.31$ & 230 & $69-207$ \\
$\mathrm{Cl}\left(\mathrm{mg} \mathrm{L}^{-1}\right)$ & $115.4 \pm 8.36$ & 400 & $140-350$ \\
$\mathrm{Cr}\left(\mathrm{mg} \mathrm{L}^{-1}\right)$ & $0.01 \pm 0.002$ & - & 0.02 \\
$\mathrm{Cu}\left(\mathrm{mg} \mathrm{L}^{-1}\right)$ & $\mathrm{ND}$ & - & 0.2 \\
$\mathrm{Mn}\left(\mathrm{mg} \mathrm{L}^{-1}\right)$ & $\mathrm{ND}$ & - & 0.2 \\
$\mathrm{Ni}\left(\mathrm{mg} \mathrm{L}^{-1}\right)$ & $0.02 \pm 0.002$ & 2 & 0.2 \\
$\mathrm{Zn}\left(\mathrm{mg} \mathrm{L}^{-1}\right)$ & $0.76 \pm 0.14$ & 5 & $<2.0$ \\
$\mathrm{Fe}\left(\mathrm{mg} \mathrm{L}^{-1}\right)$ & $3.79 \pm 0.18$ & 0.01 & $<.1-1.5$ \\
$\mathrm{Cd}\left(\mathrm{mg} \mathrm{L}^{-1}\right)$ & $0.002 \pm 0.001$ & 5 & $<0.01$ \\
$\mathrm{~Pb}\left(\mathrm{mg} \mathrm{L}^{-1}\right)$ & $3.03 \pm 0.2$ & 5.0 \\
\hline
\end{tabular}

${ }^{1}$ JISM, Jordan Institution for Standard and Metrology; ${ }^{2}$ WHO, World Health Organization; ND, not detected in samples.

Table 4. Soil chemical analysis of various nutrient and metal ions at the Wadi-Musa Wastewater Treatment Plant experimental site. The data are averages $\pm \operatorname{SD}(n=3)$.

\begin{tabular}{cc}
\hline Element & Measurement \\
\hline${\mathrm{N} \text { total }\left(\mathrm{g} \mathrm{kg}^{-1}\right)}^{\mathrm{P}\left(\mathrm{mg} \mathrm{kg}^{-1}\right)}$ & $13.3 \pm 0.3$ \\
$\mathrm{~K}\left(\mathrm{mg} \mathrm{L}^{-1}\right)$ & $93.7 \pm 7.03$ \\
$\mathrm{Na}\left(\mathrm{mg} \mathrm{L}^{-1}\right)$ & $710 \pm 44.0$ \\
${\mathrm{Cl}\left(\mathrm{mg} \mathrm{L}^{-1}\right)}_{\mathrm{Cd}\left(\mathrm{mg} \mathrm{L}^{-1}\right)}$ & $345 \pm 39.2$ \\
$\mathrm{Cr}\left(\mathrm{mg} \mathrm{L}^{-1}\right)$ & $0.15 \pm 0.05$ \\
$\mathrm{Cu}\left(\mathrm{mg} \mathrm{L}^{-1}\right)$ & $0.18 \pm 0.05$ \\
$\mathrm{Fe}\left(\mathrm{mg} \mathrm{L}^{-1}\right)$ & $0.28 \pm 0.01$ \\
$\mathrm{Mn}\left(\mathrm{mg} \mathrm{L}^{-1}\right)$ & $2.22 \pm 1.20$ \\
$\mathrm{Ni}\left(\mathrm{mg} \mathrm{L}^{-1}\right)$ & $3.45 \pm 1.54$ \\
$\mathrm{~Pb}\left(\mathrm{mg} \mathrm{L}^{-1}\right)$ & $0.16 \pm 0.03$ \\
$\mathrm{Zn}\left(\mathrm{mg} \mathrm{L}^{-1}\right)$ & $1.56 \pm 0.19$ \\
\hline
\end{tabular}

\subsection{Effects of Irrigation with TWW on Heavy Metals Content in Olive Trees}

Heavy metals analysis of leaves, roots, stem bark and fruits indicated noteworthy variations in response to continuous irrigation with TWW (Figure 2). Irrigation with TWW resulted in a significant accumulation of heavy metals in different parts of the olive tree. Variable ion contents were observed among different organs, and the highest concentration of $\mathrm{Mn}, \mathrm{Cd}$ and $\mathrm{Pb}$ (Figure 2C,G,H) were observed in the leaves compared to other organs, while $\mathrm{Cr}$ content (Figure 2E) was the highest in the stem bark. Manganese content ranged 
from $177 \%$ to $641 \%$ of that in roots and fruits, respectively (Figure 2C). A similar trend was observed with $\mathrm{Pb}$ but with values ranging from 131-191\% of that in the roots and fruits, respectively (Figure $2 \mathrm{H}$ ). On the other hand, $\mathrm{Cd}$ was the lowest in roots and fruits compared to other parts (Figure $2 \mathrm{G}$ ). The highest concentration of $\mathrm{Cr}$ was found in the stem bark (3.97 mg kg${ }^{-1}$ ) and was the lowest in the leaves $\left(1.9 \mathrm{mg} \mathrm{kg}^{-1}\right.$ ) (Figure 2E). Roots were also found to have high Fe concentrations, which were higher by $183 \%$ than that in leaves and by $636 \%$ than that in fruits (Figure 2B). Fruits were also found to have the highest concentrations of $\mathrm{Zn}, \mathrm{Cu}$ and $\mathrm{Ni}$ compared to other plant organs (Figure 2A,D,F). Moreover, $\mathrm{Cd}$ followed by $\mathrm{Cr}, \mathrm{Mn}$ and $\mathrm{Ni}$ had the lowest concentration in fruits. In all plant parts, $\mathrm{Cd}, \mathrm{Ni}$ and $\mathrm{Cr}$ had the lowest concentrations.

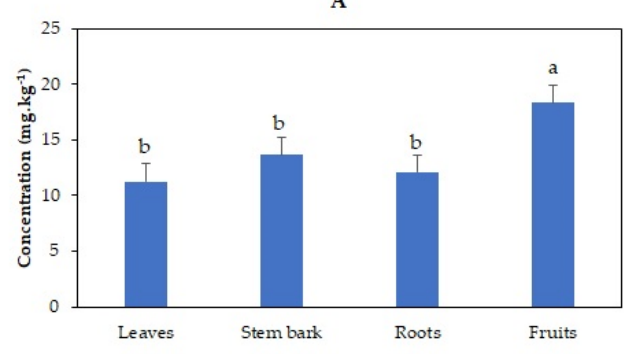

C

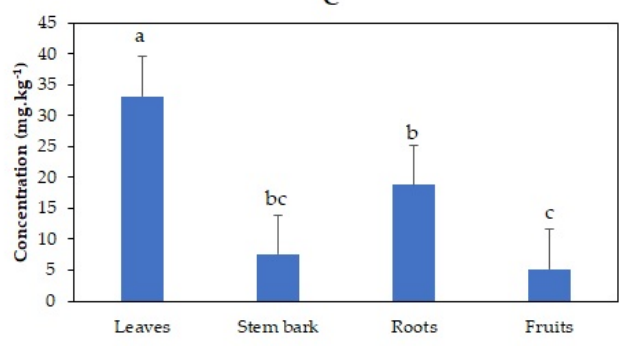

E
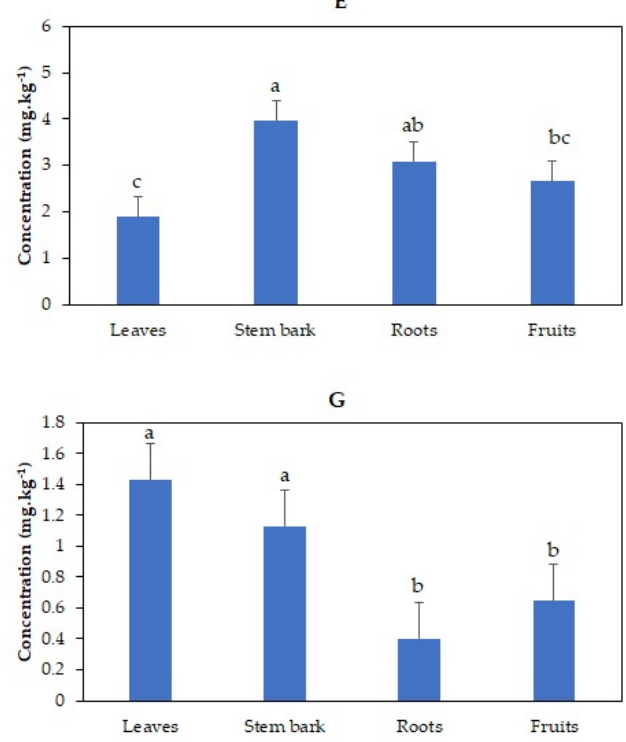

B

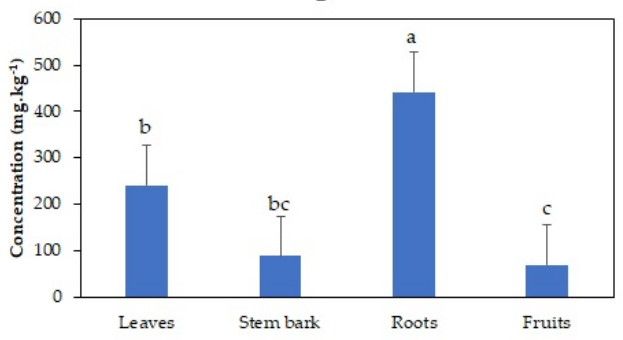

D

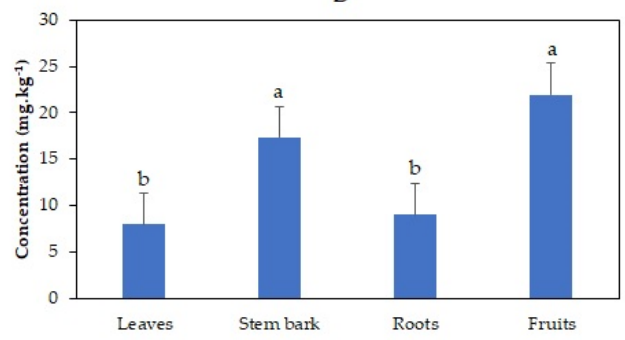

F

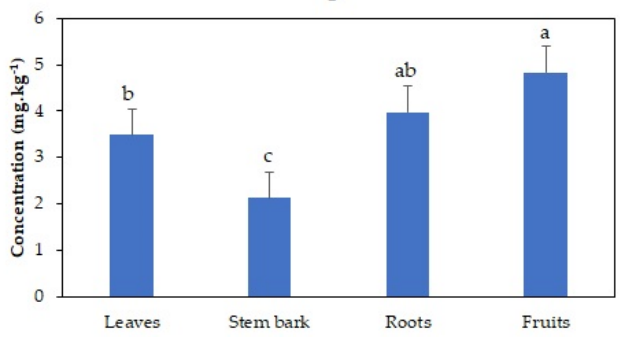

H

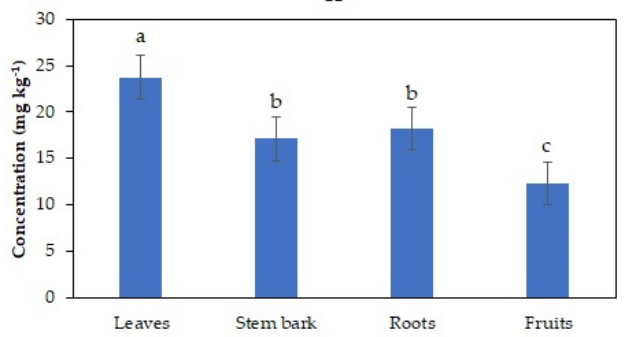

Figure 2. Concentration ( $\mathrm{mg} \mathrm{kg}^{-1}$ ) of $\mathrm{Zn}(\mathbf{A}), \mathrm{Fe}(\mathbf{B}), \mathrm{Mn}(\mathbf{C}), \mathrm{Cu}(\mathbf{D}), \mathrm{Cr}(\mathbf{E}), \mathrm{Ni}(\mathbf{F}), \mathrm{Cd}(\mathbf{G}), \mathrm{Pb}(\mathbf{H})$ in the leaves, stem bark, roots and fruits of olive trees irrigated continuously with TWW at the Wadi-Musa Wastewater Treatment Plant experimental site. Bars represent mean \pm SE. Different letters indicate a significant difference between plant parts by LSD $(p \leq 0.05)$.

Irrigating crops with TWW usually raises concern about increased heavy metals uptake by plants [49]. The presence of heavy metals in TWW, especially in that of industrial effluent, tends to accumulate in the soils, where they are potentially bioavailable for 
crops $[46,49,50]$. Although the concentrations of heavy metal ions were found to be within local and international standards [38,39], a noticeable accumulation of these elements in soil and plants was found in response to long-term irrigation with treated wastewater in this study. The results of this study agree with those found by Al-Lahham et al. [51], who reported increased levels of $\mathrm{Fe}, \mathrm{Mn}, \mathrm{Zn}, \mathrm{Cu}$ and Ni contents of TWW-irrigated tomato, which was associated with the increase in the quantity of municipal effluent used in irrigation.

The accumulation of various heavy metals in different plant parts of olive trees in the present study in response to irrigation with treated wastewater is typical for olives grown under such conditions [21,52]. Wilson and Pyatt [31] considered olive trees as important bioaccumulators of $\mathrm{Cu}, \mathrm{Pb}$, and $\mathrm{Zn}$ in their tissues and organs when grown in an area contaminated with these metals. Previous studies indicated increased Mn contents of Celosia in response to irrigation with treated effluents having high Mn levels [53].

\subsection{Effects of Irrigation with TWW on Bioconcentration Factor of Heavy Metals in Olive Trees}

The values of the BCF of heavy metals in different olive tree organs are shown in Figure 3. Bioconcentration factors of heavy metals greater than 1 were found for all elements in all studied organs. The BCF values of heavy metals in the roots were ranked as follows: $\mathrm{Fe}>\mathrm{Cu}>\mathrm{Ni}>\mathrm{Cr}>\mathrm{Zn}>\mathrm{Mn}>\mathrm{Cd}>\mathrm{Pb}$, with values ranging between 201.4 1.56 for $\mathrm{Pb}$. Similarly, the accumulation of heavy metals was in the order of $\mathrm{Cu}>\mathrm{Fe}>\mathrm{Cr}$ $>\mathrm{Zn}>\mathrm{Ni}>\mathrm{Pb}>\mathrm{Cd}>\mathrm{Mn}$ in stem bark with BFC values reaching 40.1 to 61.4 for both Fe and $\mathrm{Cu}$, respectively. It is clear that $\mathrm{BCF}$ in leaves was higher than in stem bark except for $\mathrm{Zn}$ and $\mathrm{Cr}$. The highest BFC was for Fe (110.5), while the lowest BFC was for Cd (9.6) in olive leaves (Figure 3B,G). Fruits were also found to accumulate various heavy metals at various levels. $\mathrm{BCF}$ values ranged from 1.55 for Mn (Figure $3 \mathrm{C}$ ) to 77.7 for Fe in fruits flesh (Figure 3B).

$\mathrm{BCF}$ values higher than 1 are used as an index to ensure that the plant is an accumulator for the metal from the soil to the plant tissue [54]. The results of this study agree with those of Wilson and Pyatt [31], who found that the flesh of olive fruits accumulated the highest concentration of copper and lead. On the other hand, leaves accumulated more zinc than most other tissues [28]. Similar responses were observed for other species such as Salix trees, which have a high potential for translocating $\mathrm{Cd}$ and $\mathrm{Zn}$ from soil to their parts [54]. Other tree species such as Paulownia fortunei and Broussonetia papyrifera exhibit high BCF values in their tissues for metals such as $\mathrm{Pb}, \mathrm{Zn}$, and $\mathrm{Cd}$ [55].

The average $\mathrm{BCFs}$ were variable among different plant parts where higher $\mathrm{BCF}$ values of Fe and $\mathrm{Cr}$ (201.4, and 17.6, respectively) were observed in roots than in leaves (110.5 and 10.7, respectively) (Figure 3B,E). On the other hand, $\mathrm{Pb}$ (Figure 3H), Mn (Figure 3C), and $\mathrm{Cd}$ (Figure 3G) had higher BCF values in leaves (15.4, 9.9 and 9.6, respectively) than in roots $(1.6,5.5,2.7)$. Fruits also exhibited higher $\mathrm{Cu}$ (Figure 3D), Ni (Figure 3F), and Zn (Figure 3A) BCF values (77.7, 30.2 and 23.8, respectively) than leaves, stem bark and roots, whereas Fe (Figure 3B) and Cd (Figure 3G) within fruits exhibited lower BCF values (31.5 and 1.7, respectively) than other organs. Chromium was found to accumulate at higher levels in stem bark with a BCF 13.3 (Figure 3E). Heavy metals with higher BCF values have easy routes with a greater opportunity to translocate to tree fruits [56]. High BCF results were reported results for Eruca sativa, Brassica campestris and Triticum aestivum irrigated with wastewater for $\mathrm{Cd}, \mathrm{Cr}$ and $\mathrm{Pb}$, that present risks to human beings [57].

\subsection{Effects of Irrigation with TWW on Translocation Factor of Heavy Metal in Olive Trees}

The translocation factor (TF) was measured to indicate the level of heavy metals transferred from roots to other organs. Figure 4 illustrates the TF of heavy metals in the different parts of olive trees. The translocation factor from roots to stem bark exhibited the following descending trends $\mathrm{Pb}>\mathrm{Cd}>\mathrm{Cu}>\mathrm{Cr}>\mathrm{Zn}>\mathrm{Ni}>\mathrm{Mn}>\mathrm{Fe}$. A similar trend was seen in TF and metal mobility from olive roots to leaves, with TF values in descending order as follows: $\mathrm{Pb}>\mathrm{Cd}>\mathrm{Mn}>\mathrm{Zn}>\mathrm{Cu}>\mathrm{Ni}>\mathrm{Cr}>\mathrm{Fe}$ (Figure 4). Lead (Figure $4 \mathrm{H}$ ) was most actively translocated to olive tree leaves with a TF value of $10 . \mathrm{Cd}$ 
(Figure 4G) and Mn (Figure 4C) had TF values of 3.9, 1.8, respectively. On the other hand, lower translocation rates of Zn (Figure 4A), Cu (Figure 4D), Ni (Figure 4F), Cr (Figure 4E) and Fe (Figure 4B) to leaves was observed with TF values less than 1.0. Translocation of heavy metals from roots to fruits was less pronounced than between other parts. Lead (Figure $4 \mathrm{H}$ ), $\mathrm{Cu}$ (Figure 4D), Zn (Figure 4A) and Ni (Figure 4F) were translocated to fruits at high ratios with TF values of 5.25, 2.45, 1.52, 1.23, respectively. By contrast, $\mathrm{Cr}$ (Figure 4E), Cd (Figure 4G), Fe (Figure 4B) and Mn (Figure 4C) exhibited lower TF values $(<1.0)$.
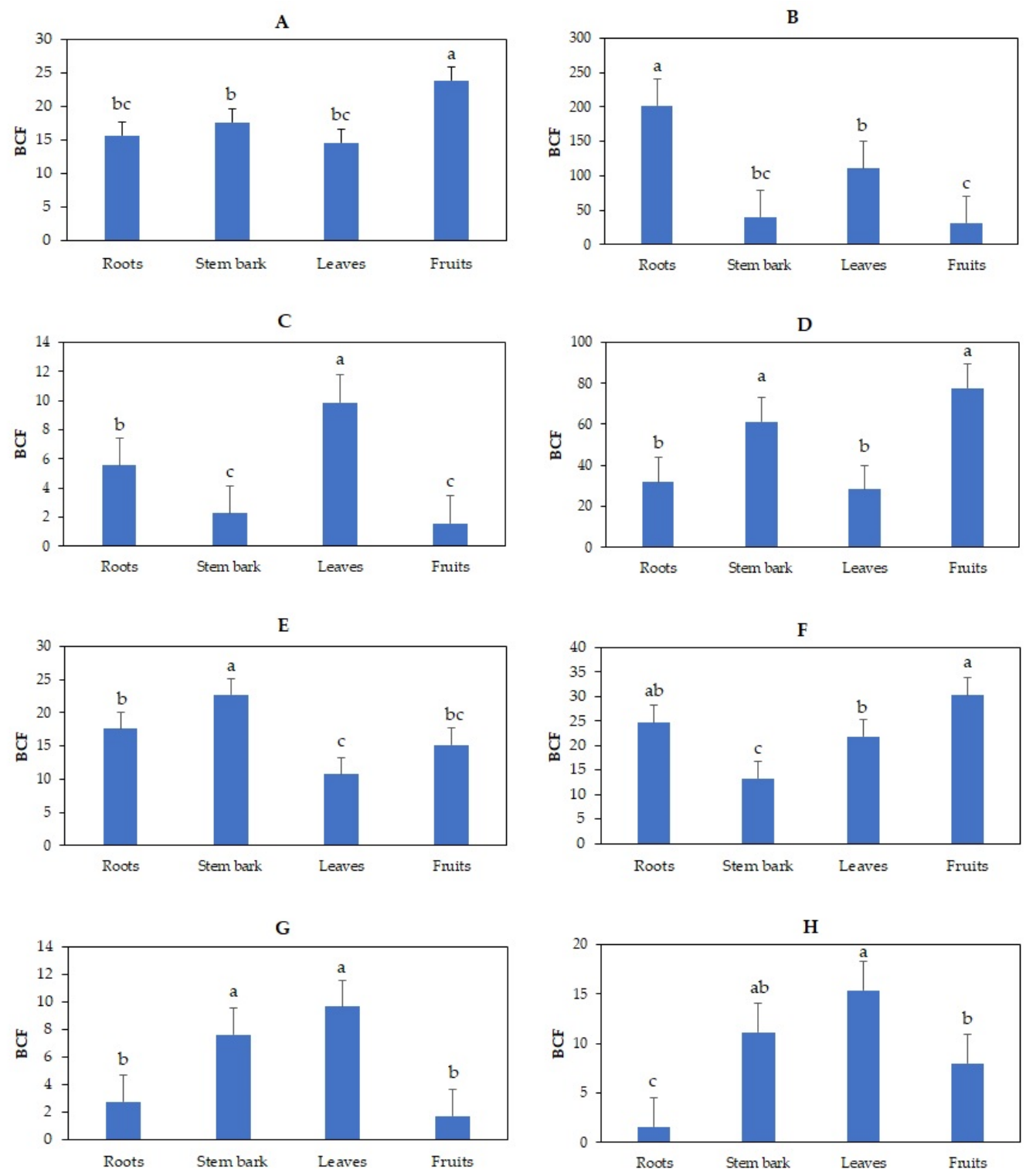

Figure 3. Bioconcentration factor (BCF) of $\mathrm{Zn}(\mathbf{A}), \mathrm{Fe}(\mathbf{B}), \mathrm{Mn}(\mathrm{C}), \mathrm{Cu}(\mathbf{D}), \mathrm{Cr}(\mathbf{E}), \mathrm{Ni}(\mathbf{F}), \mathrm{Cd}(\mathrm{G}), \mathrm{Pb}(\mathrm{H})$ in different parts of olive trees irrigated with treated wastewater at the Wadi-Musa Wastewater Treatment Plant experimental site. Bars represent mean \pm SE. Different letters indicate significant differences between plant parts by LSD $(p \leq 0.05)$. 


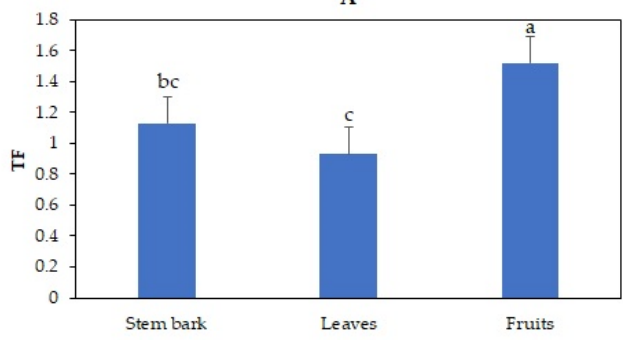

C

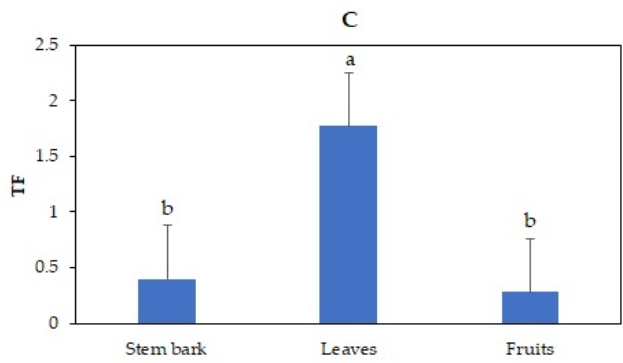

E

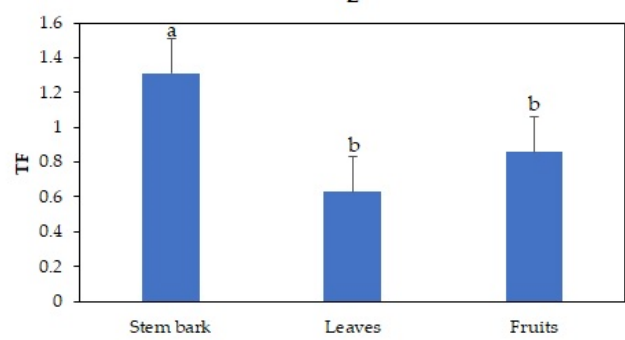

G

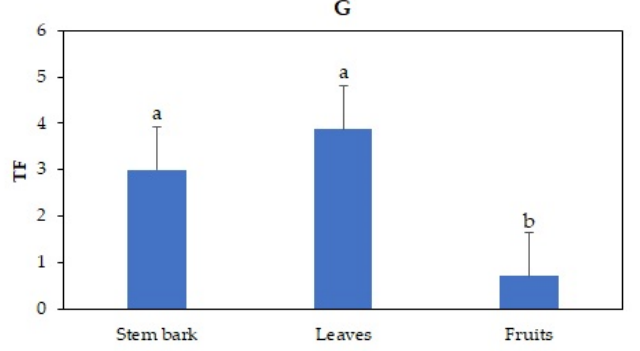

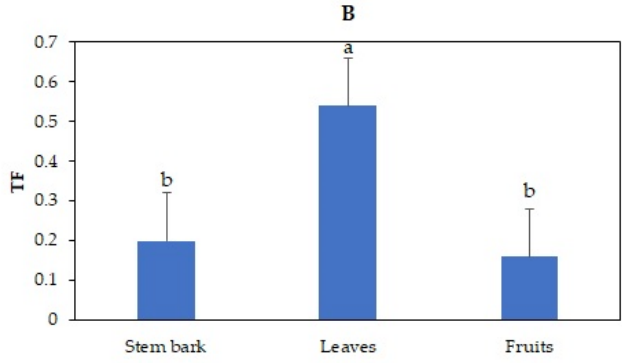

D

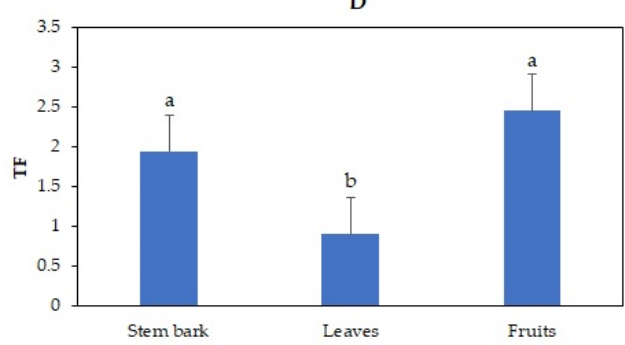

F

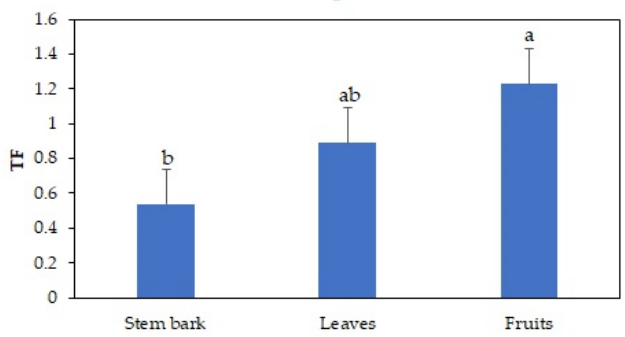

H

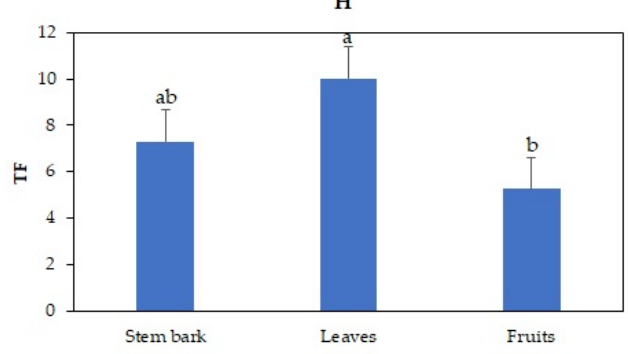

Figure 4. Translocation factors (TFs) for $\mathrm{Zn}(\mathbf{A}), \mathrm{Fe}(\mathbf{B}), \mathrm{Mn}(\mathbf{C}), \mathrm{Cu}(\mathbf{D}), \mathrm{Cr}(\mathrm{E}), \mathrm{Ni}(\mathrm{F}), \mathrm{Cd}(\mathrm{G}), \mathrm{Pb}(\mathbf{H})$ in the different parts of olive trees irrigated continuously with TWW at the Wadi-Musa Wastewater Treatment Plant experimental site. Bars represent mean \pm SE. Different letters indicate significant differences between plant parts by LSD $(p \leq 0.05)$.

Higher TF values for olive leaves than stem bark and fruits were found for $\mathrm{Fe}$ (Figure 4B), Mn (Figure 4C), Cd (Figure 4G) and Pb (Figure 4 (H) (0.54, 1.77, 3.87 and 5.25 , respectively), whereas $\mathrm{Cu}$ (Figure $4 \mathrm{D}$ ) had a lower TF to leaves $(0.89)$ than for bark and fruits (1.94 and 2.45), respectively. Higher translocation rates to fruits than that to bark and leaves were observed for $\mathrm{Zn}$ (Figure 4A), $\mathrm{Cu}$ (Figure 4D) and Ni (Figure 4F) with TF values of 1.5, 2.5 and 1.2, respectively. Moreover, $\mathrm{Cr}$ (Figure 4E) was the only metal that exhibited higher significant translocation to the olive bark than to other parts with a TF value of 1.3. These results are consistent with the results of Mehmood et al. [57] and Lu et al. [58]. Bioconcentration factor and TF are used to determine if a plant is an accumulator or excluder for heavy metals $[58,59]$. Plants featuring a $\mathrm{TF}<1$ are considered excluders that can inhibit metal entrance into the plant or restrict root-to-shoot translocation [57]. 


\section{Conclusions}

This study investigated the influence of long-term use of treated wastewater on uptake and partitioning of heavy metals in olive trees. Results indicate that long term irrigation of TWW over the past fifteen years resulted in the accumulation of corresponding heavy metals in olive trees. Moreover, the uptake and portioning of various heavy metals by different plant parts (roots, leaves, stem bark, and fruits) were correlated to their concentration in treated wastewater and soil. Higher levels of $\mathrm{Zn}, \mathrm{Cu}, \mathrm{Cr}$, and $\mathrm{Ni}$ were accumulated in olive fruits than in leaves. However, more $\mathrm{Mn}, \mathrm{Cd}$ and $\mathrm{Pb}$ were also found in leaves compared to other parts. Only $\mathrm{Fe}$ and $\mathrm{Cr}$ were found in higher concentrations in roots and stem bark than in fruits and leaves, respectively. The bioaccumulation factor of heavy metals from the soil to different plant parts indicates selective absorption and partitioning of these heavy metals. High BCF values $>1$ was found in roots of olive trees with the following descending order: $\mathrm{Fe}>\mathrm{Cu}>\mathrm{Ni}>\mathrm{Cr}>\mathrm{Zn}>\mathrm{Mn}>\mathrm{Cd}>\mathrm{Pb}$. A similar trend was observed for fruit $\mathrm{BFC}$ values with the following order: $\mathrm{Cu}>\mathrm{Fe}>\mathrm{Ni}>\mathrm{Zn}>$ $\mathrm{Cr}>\mathrm{Pb}>\mathrm{Cd}>\mathrm{Mn}$. On the other hand, leaf $\mathrm{BFC}$ values indicated higher Fe, Mn, Cd, and $\mathrm{Pb}$ than those for other parts. Translocation factors of various heavy metals were variable among plant parts of olive trees. Fruits had the highest TF values for $\mathrm{Cu}, \mathrm{Cd}$ and $\mathrm{Zn}$, and the lowest for $\mathrm{Mn}$ and Fe, while leaves had the highest TF values for Fe, $\mathrm{Zn}$ and $\mathrm{Mn}$ and the lowest for $\mathrm{Cd}$ and $\mathrm{Pb}$. Stem bark was different in its TF, with the highest value for $\mathrm{Cr}$. In conclusion, olive trees are heavy metals accumulators and, therefore, caution should be considered in long-term use of TWW. Periodic assessment of possible hazards, especially on fruits and oil quality, is required.

Author Contributions: K.A.A.-H. and R.S.A.-S. conceived, designed the experiments, analyzed the data and wrote the manuscript. J.S.A.-H., M.B.A.-N. and R.N.A. helped in soil, water, and chemical analysis. J.Y.A. and H.S.A.-D. helped in data and statistical analysis and manuscript preparation. All authors edited and provided a critical review of the manuscript. All authors have read and agreed to the published version of the manuscript.

Funding: This research was partially funded by the deanship of scientific research/Al-Balqa Applied University.

Institutional Review Board Statement: Not applicable.

Informed Consent Statement: Not applicable.

Data Availability Statement: The data sets supporting the results of this article will be freely available upon request to corresponding author.

Acknowledgments: We sincerely acknowledged Professor Ayed Al Abdallat for his scientific advice.

Conflicts of Interest: The authors have declared that no conflict of interest exists.

\section{References}

1. Al-Bakri, J.; Suleiman, A.; Abdulla, F.; Ayad, J. Potential impact of climate change on rainfed agriculture of a semi-arid basin in Jordan. Phys. Chem. Earth Parts A/B/C 2011, 36, 125-134. [CrossRef]

2. Rad, S.V.; Valadabadi, S.A.R.; Pouryousef, M.; Saifzadeh, S.; Zakrin, H.R.; Mastinu, A. Quantitative and Qualitative Evaluation of Sorghum bicolor L. under Intercropping with Legumes and Different Weed Control Methods. Horticulturae 2020, 6, 78. [CrossRef]

3. Al-Satari, Y.; Al-Ramamneh, E.A.-D.; Ayad, J.; Abu Dalbouh, M.; Amayreh, I.; Khreisat, Z. Impact of seedling age on the survival and productivity of Atriplex halimus shrubs in drought-affected rangelands of Jordan. Rangel. J. 2018, 40, 287-296. [CrossRef]

4. United Nations Development Programme; Sustainable development goals; UNDP Jordan: Amman, Jordan, 2019.

5. Qtaishat, T. Water Policy in Jordan. In Water Policies in MENA Countries, 1st ed.; Zekri, S., Ed.; Global Issues in Water Policy; Springer: Cham, Germany, 2020; Volume 23. [CrossRef]

6. Heras, J.D.L.; Mañas, P. Reclaimed Wastewater to Irrigate Olive Groves and Vineyards: Effects on Soil Properties. Agronomy 2020, 10, 649. [CrossRef]

7. Gharsallaoui, M.; Benincasa, C.; Ayadi, M.; Perri, E.; Khlif, M.; Gabsi, S. Study on the impact of wastewater irrigation on the quality of oils obtained from olives harvested by hand and from the ground and extracted at different times after the harvesting. Sci. Hortic. 2011, 128, 23-29. [CrossRef]

8. DOS. Department of Statistics Year Book; Jordan Department of Statistics: Amman, Jordan, 2019. Available online: http://www.dos. gov.jo (accessed on 15 March 2021). 
9. Duqqah, M.M. Treated Sewagewater Use in Irrigated Agriculture: Theoretical Design of Farming Systems in Seil Al Zarqa and the Middle Jordan Valley in Jordan. Ph.D. Thesis, Wageningen University, Wageningen, The Netherlands, 2002.

10. Stietiya, M.H.; Duqqah, M.; Udeigwe, T.; Zubi, R.; Ammari, T. Fate and Distribution of Heavy Metals in Wastewater Irrigated Calcareous Soils. Sci. World J. 2014, 2014, 1-11. [CrossRef] [PubMed]

11. Al-Nakshabandi, G.; Saqqar, M.; Shatanawi, M.; Fayyad, M.; Al-Horani, H. Some environmental problems associated with the use of treated wastewater for irrigation in Jordan. Agric. Water Manag. 1997, 34, 81-94. [CrossRef]

12. Al-Zu'Bi, Y. Effect of irrigation water on agricultural soil in Jordan valley: An example from arid area conditions. J. Arid. Environ. 2007, 70, 63-79. [CrossRef]

13. Ghrefat, H.A.; Yusuf, N.; Jamarh, A.; Nazzal, J. Fractionation and risk assessment of heavy metals in soil samples collected along Zerqa River, Jordan. Environ. Earth Sci. 2012, 66, 199-208. [CrossRef]

14. Abderahman, N.; Abu-Rukah, Y.H. An assessment study of heavy metal distribution within soil in upper course of Zarqa River basin/Jordan. Environ. Earth Sci. 2006, 49, 1116-1124. [CrossRef]

15. Al Farajat, M.; Al Ansari, N.; Mashagbeh, A.; Abou Salah, R. Hydrogeophysical and environmental investigations of groundwater potentials in Al Sokhna alluvium aquifer in Zarqa-Jordan. Hydrogeol. Umw. 2005, 7, 1-15.

16. Mishra, A.K.; Sahu, A.; Deepika, A.S.; Gauba, P. Phytoremediation of Heavy Metals. J. Pharm. Res. 2014, 8, 1233-1238.

17. Li, Z.; Ma, Z.; van der Kuijp, T.J.; Yuan, Z.; Huang, L. A review of soil heavy metal pollution from mines in China: Pollution and health risk assessment. Sci. Total. Environ. 2014, 468-469, 843-853. [CrossRef] [PubMed]

18. Toze, S. Reuse of effluent water-Benefits and risks. Agric. Water Manag. 2006, 80, 147-159. [CrossRef]

19. Al-Hiary, M.A.H. Assessing Competitiveness of Jordanian Olive Production a Policy Analysis Matrix Pam. J. Stud. Manag. Plan. 2015, 1, 19-29.

20. Ministry of Agriculture, Annual Reports, Department of Studies and Statistics, Amman-Jordan. 2016. Available online: www. moa.gov.jo (accessed on 15 March 2021).

21. Ayoub, S.; Al-Shdiefat, S.; Rawashdeh, H.; Bashabsheh, I. Utilization of reclaimed wastewater for olive irrigation: Effect on soil properties, tree growth, yield and oil content. Agric. Water Manag. 2016, 176, 163-169. [CrossRef]

22. Filippou, M.; Fasseas, C.; Karabourniotis, G. Photosynthetic characteristics of olive tree (Olea europaea) bark. Tree Physiol. 2007, 27, 977-984. [CrossRef]

23. Bourazanis, G.; Roussos, P.; Argyrokastritis, I.; Kosmas, C.; Kerkides, P. Evaluation of the use of treated municipal waste water on the yield, oil quality, free fatty acids' profile and nutrient levels in olive trees cv Koroneiki, in Greece. Agric. Water Manag. 2016, 163, 1-8. [CrossRef]

24. Freihat, N.M.; Shannag, H.K.; Alkelani, M.A. Effects of supplementary irrigation on performance of 'Nabali' and 'Grossa de Spain' olives under semi-arid conditions in Jordan. Sci. Hortic. 2021, 275, 109696. [CrossRef]

25. Al-Mefleh, N.; Othman, Y.; Tadros, M.; Al-Assaf, A.; Talozi, S. An Assessment of Treated Greywater Reuse in Irrigation on Growth and Protein Content of Prosopis and Albizia. Horticulturae 2021, 7, 38. [CrossRef]

26. Bedbabis, S.; Trigui, D.; Ben Ahmed, C.; Clodoveo, M.L.; Camposeo, S.; Vivaldi, G.A.; Ben Rouina, B. Long-terms effects of irrigation with treated municipal wastewater on soil, yield and olive oil quality. Agric. Water Manag. 2015, 160, 14-21. [CrossRef]

27. Gizgis, N.; Georgiou, M.; Diamadopoulos, E. Sequential anaerobic/aerobic biological treatment of olive mill wastewater and municipal wastewater. J. Chem. Technol. Biotechnol. 2006, 81, 1563-1569. [CrossRef]

28. Bozkurt, M.A.; Yarilgaç, T. The effects of sewage sludge applications on the yield, growth, nutrition and heavy metal accu-mulation in apple trees growing in dry conditions. Turk. J. Agric. For. 2003, 27, 285-292.

29. Guo, J.; Yue, T.; Li, X.; Yuan, Y. Heavy metal levels in kiwifruit orchard soils and trees and its potential health risk assessment in Shaanxi, China. Environ. Sci. Pollut. Res. 2016, 23, 14560-14566. [CrossRef]

30. Peryea, F.J. Heavy metal contamination in deciduous tree fruit orchards: Implications for mineral nutrient management. Acta Hortic. 2001, 564, 31-39. [CrossRef]

31. Wilson, B.; Pyatt, F.B. Heavy Metal Bioaccumulation by the Important Food Plant, Olea europaea L., in an Ancient Metalliferous Polluted Area of Cyprus. Bull. Environ. Contam. Toxicol. 2007, 78, 390-394. [CrossRef]

32. Batarseh, M.I.; Rawajfeh, A.; Ioannis, K.K.; Prodromos, K.H. Treated Municipal Wastewater Irrigation Impact on Olive Trees (Olea Europaea L.) at Al-Tafilah, Jordan. Water Air Soil Pollut. 2010, 217, 185-196. [CrossRef]

33. Luka, M.F.; Akun, E. Investigation of trace metals in different varieties of olive oils from northern Cyprus and their variation in accumulation using ICP-MS and multivariate techniques. Environ. Earth Sci. 2019, 78, 578. [CrossRef]

34. López-López, A.; López, R.; Madrid, F.; Garrido-Fernández, A.; López-Núñez, R. Heavy Metals and Mineral Elements Not Included on the Nutritional Labels in Table Olives. J. Agric. Food Chem. 2008, 56, 9475-9483. [CrossRef] [PubMed]

35. Paithankar, J.G.; Saini, S.; Dwivedi, S.; Sharma, A.; Chowdhuri, D.K. Heavy metal associated health hazards: An interplay of oxidative stress and signal transduction. Chemosphere 2021, 262, 128350. [CrossRef] [PubMed]

36. Järup, L. Hazards of heavy metal contamination. Br. Med. Bull. 2003, 68, 167-182. [CrossRef] [PubMed]

37. Addison, E. Political effluent: Implementing wastewater re-use in Wadi Musa, Jordan. Arid. Newsl. University of Arizona: Tucson, AZ, USA, 2005; Volume 57, pp. 1-18; ISSN 1092-5481. Available online: http:/ / ag.arizona.edu/oals/ALN/aln57/addison.html (accessed on 24 March 2021).

38. JISM. Water—Reclaimed Grey Water (JS 1776:2013); Jordan Standards and Metrology Organization: Amman, Jordan, 2013; pp. 1-12. 
39. WHO. Guidelines for the Safe Use of Wastewater, Excreta and Greywater; World Health Organization: Geneva, Switzerland, 2006; Volume 2.

40. Duncan, H.J.; Flowers, T.H.; Pulford, I.D.; Wilson, W.D. Analytical Procedures for the Analysis of Heavy Metals in Contaminated Soils. In Contaminated Soil'95, 2nd ed.; Van Den Brink, W.J., Bosman, R., Arendt, F., Eds.; Soil \& Environment; Springer: Dordrecht, The Netherlands, 1995; Volume 5, pp. 731-732.

41. Estefan, G.; Sommer, R.; Ryan, J. Methods of Soil, Plant, and Water Analysis. A Manual for the West Asia and North Africa Region, 3rd ed.; ICARDA: Beirut, Lebanon, 2013; pp. 20-199.

42. Mellem, J.J. Bioaccumulation of $\mathrm{Cr}, \mathrm{Hg}, \mathrm{As}, \mathrm{Pb}, \mathrm{Cu}$ and $\mathrm{Ni}$ with the ability for hyperaccumulation by Amaranthus dubius. Afr. J. Agric. Res. 2012, 7, 591-596. [CrossRef]

43. Al-Khashman, O.A. Chemical Evaluation of Ma'an Sewage Effluents and its Reuse in Irrigation Purposes. Water Resour. Manag. 2008, 23, 1041-1053. [CrossRef]

44. Bedbabis, S.; Ben Rouina, B.; Boukhris, M.; Ferrara, G. Effect of irrigation with treated wastewater on soil chemical properties and infiltration rate. J. Environ. Manag. 2014, 133, 45-50. [CrossRef]

45. Emongor, V.; Ramolemana, G. Treated sewage effluent (water) potential to be used for horticultural production in Botswana. Phys. Chem. Earth Parts A/B/C 2004, 29, 1101-1108. [CrossRef]

46. Heidarpour, M.; Mostafazadeh-Fard, B.; Koupai, J.A.; Malekian, R. The effects of treated wastewater on soil chemical properties using subsurface and surface irrigation methods. Agric. Water Manag. 2007, 90, 87-94. [CrossRef]

47. Klay, S.; Charef, A.; Ayed, L.; Houman, B.; Rezgui, F. Effect of irrigation with treated wastewater on geochemical properties (saltiness, C, N and heavy metals) of isohumic soils (Zaouit Sousse perimeter, Oriental Tunisia). Desalination 2010, 253, 180-187. [CrossRef]

48. Dikinya, O.; Areola, O. Comparative analysis of heavy metal concentration in secondary treated wastewater irrigated soils cultivated by different crops. Int. J. Environ. Sci. Technol. 2010, 7, 337-346. [CrossRef]

49. Al-Absi, K.; Al-Nasir, F.; Mahadeen, A. Mineral content of three olive cultivars irrigated with treated industrial wastewater. Agric. Water Manag. 2009, 96, 616-626. [CrossRef]

50. Ernst, W.H.O. Evolution of metal tolerance of plants. For. Snow Landsc. Res. 2006, 80, 251-274.

51. Al-Lahham, O.; El Assi, N.; Fayyad, M. Translocation of heavy metals to tomato (Solanum lycopersicom L.) fruit irrigated with treated wastewater. Sci. Hortic. 2007, 113, 250-254. [CrossRef]

52. Petousi, I.; Fountoulakis, M.; Saru, M.; Nikolaidis, N.; Fletcher, L.; Stentiford, E.; Manios, T. Effects of reclaimed wastewater irrigation on olive (Olea europaea L. cv. 'Koroneiki') trees. Agric. Water Manag. 2015, 160, 33-40. [CrossRef]

53. Friedman, H.; Bernstein, N.; Bruner, M.; Rot, I.; Ben-Noon, Z.; Zuriel, A.; Zuriel, R.; Finkelstein, S.; Umiel, N.; Hagiladi, A. Application of secondary-treated effluents for cultivation of sunflower (Helianthus annuus L.) and celosia (Celosia argentea L.) as cut flowers. Sci. Hortic. 2007, 115, 62-69. [CrossRef]

54. Pulford, I.D.; Dickinson, N.M. Phytoremediation Technologies Using Trees. In Trace Elements in the Environment: Biogeochemistry, Biotechnology, and Bioremediation, 1st ed.; Prasad, M.N.V., Sajwan, K.S., Naidu, R., Eds.; CRC Press: New York, NY, USA, 2005; Volume 383, pp. 283-404. [CrossRef]

55. Zhao, X.; Liu, J.; Xia, X.; Chu, J.; Wei, Y.; Shi, S.; Chang, E.; Yin, W.; Jiang, Z. The evaluation of heavy metal accumulation and application of a comprehensive bio-concentration index for woody species on contaminated sites in Hunan, China. Environ. Sci. Pollut. Res. 2014, 21, 5076-5085. [CrossRef] [PubMed]

56. Luo, C.; Liu, C.; Wang, Y.; Liu, X.; Li, F.; Zhang, G.; Li, X. Heavy metal contamination in soils and vegetables near an e-waste processing site, south China. J. Hazard. Mater. 2011, 186, 481-490. [CrossRef] [PubMed]

57. Mehmood, A.; Mirza, M.A.; Choudhary, M.A.; Kim, K.-H.; Raza, W.; Raza, N.; Lee, S.S.; Zhang, M.; Lee, J.-H.; Sarfraz, M. Spatial distribution of heavy metals in crops in a wastewater irrigated zone and health risk assessment. Environ. Res. 2019, 168, 382-388. [CrossRef]

58. Lu, Y.; Yao, H.; Shan, D.; Jiang, Y.; Zhang, S.; Yang, J. Heavy Metal Residues in Soil and Accumulation in Maize at Long-Term Wastewater Irrigation Area in Tongliao, China. J. Chem. 2015, 2015, 1-9. [CrossRef]

59. Wahsha, M.; Bini, C.; Argese, E.; Minello, F.; Fontana, S.; Wahsheh, H. Heavy metals accumulation in willows growing on Spolic Technosols from the abandoned Imperina Valley mine in Italy. J. Geochem. Explor. 2012, 123, 19-24. [CrossRef] 